This item was submitted to Loughborough's Research Repository by the author.

Items in Figshare are protected by copyright, with all rights reserved, unless otherwise indicated.

\title{
Screening for Erdoğanism: television, post-truth and political fear
}

PLEASE CITE THE PUBLISHED VERSION

https://doi.org/10.1177/0267323120903680

PUBLISHER

SAGE Publications

VERSION

AM (Accepted Manuscript)

\section{PUBLISHER STATEMENT}

This paper was accepted for publication in the journal European Journal of Communication and the definitive published version is available at https://doi.org/10.1177/0267323120903680. Users who receive access to an article through a repository are reminded that the article is protected by copyright and reuse is restricted to non-commercial and no derivative uses. Users may also download and save a local copy of an article accessed in an institutional repository for the user's personal reference.

\section{LICENCE}

CC BY-NC-ND 4.0

\section{REPOSITORY RECORD}

Celik, Burce. 2020. "Screening for Erdoğanism: Television, Post-truth and Political Fear". Loughborough University. https://hdl.handle.net/2134/11357750.v1. 


\title{
Screening for Erdoğanism: Television, post-truth and political fear
}

\author{
Burçe Çelik
}

\begin{abstract}
The majority of current political communication studies focuses on digital and social media, and overlooks the centrality of television for the production and endurance of strongman politics in the Global South. By focusing on the journalistic television productions aired during the June 2018 election period in Turkey, this article unpacks the televisual logic that is incarnated in different modalities of telling and narrating of televisual genres. I propose two main themes: the 'political fear' of physical and social security threats, and 'post-truth communications' as the main televisual idioms for a vision of the future that is either secure or chaotic, that is, with or without Erdoğan. By combining political economy, content and textual analysis, I scrutinise the production dynamics of the televisual economy and the control and content of factual segments.
\end{abstract}

\author{
Keywords \\ Authoritarianism, elections, fear, post-truth, television, Turkey
}

\section{Introduction}

In June 2018, Recep Tayyip Erdoğan won the most critical vote in the history of modern Turkey. He assumed the presidential office imbued with sweeping executive powers that voters narrowly approved in a constitutional referendum in 2017. This electoral victory not only legalised Erdoğan's de facto one-man regime as de jour but also initiated a new Republican period that officially ended the parliamentary political system that had been in effect since the mid 1940s. It also showed that the (slim) majority of voters affirmed Erdoğanism as a viable political regime despite the ongoing curtailment of democracy, emerging economic crisis, troubling foreign relations and the marginalisation of all opposition groups in line with his divisive policies and discourses. Erdoğanism, the political scientist Ahmet Insel (2018) explains, defines an electoral autocracy where elections create a democratic and competitive façade although they are neither fair nor equal (see also Schedler, 2002). The support of voter groups is thus concentrated into the cult of leadership rather than party politics and ideology (Bora, 2017; Y1lmaz and Bashirov, 2018). This constitutes a new political economy of development and welfare, which is variously termed as 'neo-patrimonial developmentalism' (Y1lmaz, 2018), 'neoliberal populism' ( nis, 2016) or 'social neo- liberalism' (Dorlach, 2015). In this new economy, state resources and rents are distributed among the politically loyal working and middle classes, and the Islamist business elite. Erdoğanism articulates its own truth regime, by systematically altering facts and providing a grotesque interpretation of reality to spread fear, mistrust and hatred towards any conflicting truth claims (see Akın, 2016).

My argument is that television - as an industry and meaning production machinery - plays a key role in the endurance of Erdoğanism. As in many countries around the world, despite the exponential growth of digital and social media, television in Turkey continues to be the most consumed medium and constitutes both a major player in the advertising industry and an influential electoral tool for political mediation (Maxwell and Miller, 2018; Morgan and Shanahan, 2017; Oates, 2017). Turkey ranks first in the daily television consumption in the world with 5.5 hours of viewership per day (Radyo Televizyon Yayıncıları Meslek Birliği (RATEM), 2018). Only $6 \%$ of Erdoğan's supporters, who largely come from rural backgrounds and define themselves as culturally conservative and religiously Sunni Muslim, working or lower middle class and are above 35 years of age, do not use television as the main platform for news. A total of $49 \%$ of these voters do not read newspapers and $39 \%$ never use the Internet (KONDA, 2014, 2018). The televisual strategy of strongman politics exploits this relationship to multiply and diversify the modes of telling, while simultaneously narrating a unified and coherent narrative. On screens that are almost universally controlled by Erdoğan's administration not only is the political campaign permanent and dispersed across popular genres (Ornstein and Mann, 2000), the leader is also unavoidable. Erdoğan speaks two to three times a day and his sermonic and combative speeches are broadcasted live, quoted in news bulletins and contextualised in debate programmes. 
As a trendsetter of neoliberal personalised autocracy, Erdoğanism uses the entirety of televisual broadcasting to form complementary yet distinct modalities and styles of telling and narrating its truth regime. Each genre and channel undertakes a different role to form, articulate and contextualise the political idioms and forms of the televised truth regime. Rather than arguing for a direct parallel between the television representation and Erdoğan's electoral victory in the historic 2018 elections, the following will show the ways in which television was adopted by the neoliberal strognman regime as the key pedagogic medium to indoctrinate viewers into the rules, lifeworlds and truth regime of the personalised autocracy. I will first provide contextual information about the historic elections and introduce conceptual frameworks for understanding the televisual truth regime, and political fear. This will be followed by a comprehensive and relational analysis of televisual messages and genres.

\section{Context of the 2018 elections}

In April 2018, Erdoğan announced snap votes for parliamentary and presidential elections that were originally scheduled for 2019. The main incentive behind the decision to call snap votes was widely believed to be the lack of time the new dates would allow for potential serious rivals to campaign against Erdoğan and for the opposition to organise for the elections (Uras, 2016). Erdoğan entered the elections as the Presidential candidate for his party, the AKP (Justice and Development Party), and for his coalition partner since 2015, the MHP (Nationalist People's Party). The divided opposition: the secularist-Kemalist CHP (Republican People's Party the oldest party in the Turkish political landscape founded by Mustafa Kemal); the breakaway nationalists (they founded the IYİ (Good) Party before the June elections); the Islamist Saadet (Felicity) Party; and the centre right Democratic Party, formed a coalition for the parliamentary elections in a bid to overcome the prohibitive $10 \%$ threshold and increase their seats in the parliament. The oppositional coalition had their own candidates for President: Muharrem İnce for the CHP, Meral Akşener for the IYI Party (the only female contestant) and Temel Karamollaoğlu for the Islamist Saadet Party. The elections were held under Emergency Rule and deeply obstructed the oppositional parties' campaigns.

Although the pro-Kurdish HDP (People's Democratic Party) is one of the key oppositional parties in Turkish politics that garners support from Kurds, as well as the democratic left, the party was excluded from the opposition alliance due to a long-running campaign by the Erdoğan administration designed to criminalise the pro-Kurdish party and its popular leader, Selahaddin Demirtaş. In such criminalising discourses, the HDP was linked to the PKK (Partiya Karkarên Kurdistanê, which pursues an armed movement for the ethnic and political rights of the Kurds of Turkey since 1984 and is also linked to the YPG (Yekîneyên Parastina Gel) in Syria). Demirtaş was imprisoned in 2016 and became the first imprisoned candidate to run for President in the history of Turkey.

The manifesto for the oppositional coalition pledged to reverse the presidential system, unite the divided society and democratise state institutions and state-society relations. Performing unexpectedly well in his rallies and campaigns, the secularist-populist Ince was considered by many oppositional groups to be a popular candidate against the invincible Erdoğan. At the beginning of his campaign, İnce paid a visit to Demirtaş in prison as a gesture symbolising his intention to unite the divided society. All oppositional parties, including the HDP, pledged to unite behind whoever was selected to challenge Erdoğan in the second round. In online spaces and the few left-leaning newspapers where oppositional voices and professional journalists could find a voice, commentators discussed the possibility of a 'deep wave' that might overthrow Erdoğan's regime with the votes of former AKP supporters who might be unhappy with the economic decline and social unrest.

In the run-up to the elections, Erdoğan's administration intensified military operations in the Kurdish populated areas on its borders, provided extra benefits to pensioners and welfare aid to the lower middle classes and promised to end emergency rule after the elections. Throughout the campaign period, Erdoğan received his highest levels of television coverage ( $89 \%$ of coverage on public channels and $58.7 \%$ on some of the mainstream commercial channels' election coverage; Organization for Security and Co-operation in Europe (OSCE), 2018). As it was the case for previous elections, Erdoğan rejected the oppositional leaders' call for a live televised debate. In contrast to Erdoğan, the opposition leaders largely used online resources that comprised web and satellite television channels based in Europe in order to deliver speeches, interviews and broadcast their rallies to the virtual public.

\section{Television and popular truth}


The majority of current discussions on 'fake news' or 'post-truth' as matters of incorrect knowledge focus on digital and social media, and consider these platforms as the main sites for the dissemination of misinformation, lies and contested truths. By linking the proliferation of possibilities for public expression with different epistemologies in digital platforms with the negation and deconstruction of truth as a common collective goal, scholars show how digital media contribute to the making of post-truth communication as well as populist politics (see Waisbord, 2018a; 2018b; Andrejevic, 2013). Since populism views politics as agonistic relations between 'the people' as a unified political subject and the elite, it introduces the notion of popular truth as 'the wisdom of the people' against elite lies (Waisbord, 2018b: 29). As 'people's medium' the social media relatedly generates favorable conditions for the production of popular and populist truth (see Chakravartty and Roy, 2015), and its high-speed, superficiality and brevity serve for the dissemination of truth claims based on feelings and beliefs rather than arguments, proofs and knowledge (Fuchs, 2018). The research on the contemporary posttruth and populist politics in Erdoğan's Turkey similarly focuses on the digital platforms and reveals how misinformation, lies, conspiratorial discourse as well as public lynching of dissident figures and their truth claims take place in these platforms (see Hoyng and Es, 2017; Saka, 2016; Bulut and Yörük, 2017; Koçer, 2015). Although this body of literature provides valuable insights to understand the ways in which post-truth communications shape the contemporary public communications, it largely overlooks how television -as still the most popular and consumed mass medium by large segments of populations in Turkey as well as elsewhere partakes in the production of post-truth and particularly truth regimes of strongman politics.

Writing on Putin's journalistic media, Natalia Roudakova (2017), however, provides an in-depth analysis of the ways in which mocking, trolling and the spread of mistrust and cynicism as instruments of post-truth communications becomes 'the signature aesthetic of the television programming' (p. 181). This occurs as the journalistic ethics and professional journalism as truth-seeking and truth-telling practice is eroded under the almost universally controlled television sector. When controlled by an autocratic leader like Putin and Erdoğan through the ownership ties and regulatory institutions, the neoliberal television does not simply offer open ended narrative segments (Ellis, 1992), nor does it merely 'speak about us' (Attalah, 2003: 485). Rather, television functions as the key pedagogic medium to indoctrinate viewers into the truth regime of the personalised autocracy (see Sudibyo and Nezar, 2013).

Writing in the context of Putin's mediated politics, Sarah Oates (2017) and Alister Miskimmon et al (2014) show the ways in which post-truth communication is structured not merely by lies, disinformation, fake news or propaganda entertainment but also a strategic narrative that shapes the perceptions and actions of domestic and international audiences. This strategic narrative, which is constantly and continously told in different televisual programming, feeds into the grotesque interpretation of reality and into the truth claims of the autocratic leader. As such, the continous televisual narrative becomes the platform for 'information warfare' (Oates, 2017).

Russian social psychologist Lyudmilla Petranovskaya defines this propaganda machinery as 'mass emotional rape' that 'aims to get into people's heads' (cited in Ennis, 2015). Not every individual is equally susceptible to televisual indoctrination, however, as Dallas Smythe has presciently noted, the 'audience act on the programme content. They take it and mold it in the image of their individual needs and values' (1954: 143).

In order to institute this televised propaganda machinery, the strongman politics transforms the ownership and control of the television (as well as the communicative) sector. This was precisely the case in Turkey's television industry since Erdoğan came to power in 2002. While the neoliberal restructuration processes had begun earlier than Erdoğan's tenure, his administration used the reform programmes, de/re-regulation and liberalisation processes to redesign the entire mediascape in line with their political agenda. In addition to structural adjustment policies, the counter terrorism legislations were used to tame critical and alternative media and suppress journalists (see Yeşil, 2016; Akser and Baybars-Hawks, 2012; Arsan, 2011). Following the purged coup and emergency rule in 2016, 178 media organisations including television channels, news agencies, newspaper distribution companies and print media were shut down (Media Ownership Monitor (MOM) Turkey, 2016) by the allegations that these media organisations were linked to the Gülenist movement and to the PKK. The underground Islamic Gülenist movement, which used to be an ally for Erdoğan's administration in his early tenure was accused of plotting the purged coup in 2016 and renamed as FETO (Fethullahist Terrorist Organization) by the administration. At the time of 2018 elections, $90 \%$ of the television market is owned by pro-AKP or AKP affiliated groups to serve for the production of Erdoğan's truth regimes and the political fear (Ethical Journalism Network (EJN), 2018).

\section{Political fear}


Corey Robin (2006), who provided one of the most comprehensive studies on fear, suggests that political fear works in two ways: first is the fear of some real or fabricated threat such as terrorism. Second is the fear that 'arises from the social, political, and economic hierarchies that divide a people' (p. 18). The object of first form of fear is often chosen and defined by politicians or militants, and is associated with 'a foreign enemy or some form of approximation of the alien, like drugs, criminals, and immigrants' (Robin, 2006). While the second form of fear is also manufactured and manipulated by politicians, Robin maintains, 'its specific purpose or function is internal intimidation, to use sanctions or the threat of sanctions to ensure that one group retains or augments its power at the expense of another' (p. 19). Victims of this fear believe that the social status, career or power they possess under the hierarchical and oppressive organisation of society could get lost. Their dependency for their wellbeing upon the wielders of power is often the main reason for their participation in the mechanisms of oppression. Political fear, in the first or the second mode, or the combination of, is a rational and moral emotion. As such, it is often grounded in the neoliberal values of self-care, self-interest and/or careerism in contemporary capitalist societies.

The majority of current studies in political communication and political science show how, in the contexts of elections, the first form of fear is used and instrumentalised by contemporary authoritarian and populist leaders and the collaborative media (Deacon and Smith, 2017; Gale, 2004; Wodak, 2015). Some of the studies also provide evidence of the ways in which fear alters the electoral decisions of scared voters in favour of authoritarian leaders and anti-pluralist, anti-democratic values and ethos (Getmansky and Zeitoff, 2014). However, when looking at how political fear in the second sense is manipulated by authoritarian/populist politicians to mobilise people's support, existing literature provides fewer clues. Such inquiry would require research into how neoliberal authoritarian populism creates its own political economy as well as the surrounding dis- course required to produce consent and coercion (Bruff, 2014). The analysis of political fear in both forms, as Cizre (2018) wrote, will provide an entry point into how Erdoğanism continues to reign in the Turkish political landscape despite its monumental failures to produce a positive and inclusive politics.

Over the last 16 years, Erdoğan's administration has developed a neoliberal developmentalist programme, mainly based on the construction of infrastructure and housing, and a new welfare model that 'created benefits and charity rather than citizenship rights and impersonal policies' (Somer, 2016: 490). While the construction businesses were subcontracted to the pro-AKP business class of new Islamist elite, the welfare benefits and gains were largely distributed among the informal and formal working class party supporters. This new model was built upon the privatisation of the 'productive welfare state' (Dorlach, 2015) in areas such as social services across health, education and public transportation (Eder, 2014). In due course, the pillars of the 'protective welfare state' (Dorlach, 2015) such as unionisation, labour rights, unemployment benefits and subsidies for agricultural sector has severely declined. The poverty reduction programmes created a new model of dependency where the informal working class and the unemployed received social assistance both in kind and in cash by the AKP-run municipalities and Islamic charities that are often linked to Erdoğan's party. The political economy of development and welfare has created a new middle class, a new elite, while also making a large segment of society dependent on exclusionary welfare policies (Yıldırım, 2009). Those who benefit and appreciate such services are defined as the 'real' people of Turkey - Erdoğan uses the Arabic term millet with its Islamic connotations for nation, while the material and economic services his administration provides for the wellbeing of the millet is defined as hizmet.

\section{Method}

My following analysis will focus on a content analysis of news bulletins, textual analysis of debate programmes and Erdoğan's televised campaign speeches. As I look into the dynamics of textual and intertextual productions in and between these televisual resources, I pay sustained attention to who owns and produces the circulated televisual narratives. I use quantitative data and analysis to elicit the frequency of the most manifested themes content in and across evening news bulletins. Furthermore, I draw on textual and discursive dynamics as I show how discourses of popular truth relate to collective memory, historical class distinctions and resentment as well as the imaginations of the millet (nation) and their enemies. My data collection focuses on prime time television coverage in a two weeks period between June 4 and 17 2018, and focuses on nine evening news bulletins (on the most watched and influential public TRT1, and private ATV, Kanal D, Star TV, Show TV, Fox TV, A Haber, NTV and Habertürk, see Ucankus (2018)), five debate programmes on different news channels (public TRT Haber, and private A Haber, NTV, CNNTürk and Habertürk), ten televised rallies led by Erdoğan that were broadcasted on all news channels alive. 
I used a tested model for coding themes, developed by the Turkish media scholar Mine Gencel Bek (2004) in her content analysis of news programming in Turkey. In addition to her thematic categories, I have also included news on terror and campaign coverage of contestants' speeches and rallies. Each news item begins and ends with the camera focussed on the presenter and is counted once according to the most manifested themes. For instance, if Erdoğan speaks about 'war on terror' in the news item, it is counted as incumbent coalition coverage.

\section{Erdoğan's rallies}

Erdoğan is considered to be a skilful orator, who mobilises his electoral base through his sermonic and combative speeches. During the 2018 election, he held 43 rallies and turned every public event he attended as President into a rally. In the monitored speeches, he largely followed a sequence of narration that moved through his hizmet (service) policies, strong leadership and the threats of terror.

Depending on where he speaks, he first gives information about the investments his administration have made in the region such as bridges, hospitals, schools, dorms, affordable housing and public transformation over the last 16 years. He then asks the crowd on 5 June, 'do you want more investments, more projects, and more hizmet?' He adds, 'then you know who to vote for', because he says, 'we make things, they destroy'. 'They' is always associated with the CHP and narrated in relation to historical references to the secularist and Kemalist past and historical class divisions within Turkish society. Erdoğan employs a distinctive wording and style of utterance to present his secularist rivals, such as using the prefix Bay (Mister), which connotes elitism and elite class in Turkish culture, whenever he names his rival Ince of the CHP Party as well as the deliberate mispronunciation of the party's acronym. Erdoğan also delivers historical information about the CHP, occasionally not grounded in facts, that is often designed to trigger historical resentments held by the working and rural class against the then ruling elites.

In a televised speech on 8 June, he recounted his early schooling years with overcrowded classes, 'when I went to the school with seventy five students, it was the CHP who ruled the country, it was the years of single party period'. This refers to a period some 30 years before he was born and also to a problem that continues to exist in some rural areas of the contemporary Turkey. Importantly, the single-party period (which lasted from the foundation of the Turkish Republic in the early 1920s to the late 1940s) has a significant negative place in the collective memory of agricultural workers and the rural classes of Turkey. This is largely due to the then CHP's policies to expropriate agricultural surplus and undertake military mobilisation in the context of Second World War (Pamuk, 2012). Erdoğan asks the crowd on 6 June, 'have they ever done anything for you? Have you ever seen them finding solutions for the neglected people's problems?' Erdoğan states that not only had the CHP done nothing for the real people of Turkey in the past, but 'God forbids, if they come to power, they will take everything you've gained'.

Referring to the news coverage on partisan channels, Erdoğan says on 9 June, 'they will close hospitals, they will sell bridges', and states 'they've said these things on television'. He refers to Ince's criticism of citizens having to pay a high toll fee to use privately operated bridges that were constructed by pro-AKP firms under a build-operate-transfer model. Ince's critique of the political economy of Erdoğanism, that it is based on the privatisation and construction of infrastructure followed by the distribution of rents among the clientele class, was deliberately misconstrued. This critique was picked, edited and presented with commentaries on partisan news bulletins to provide the impression that Ince would destroy these constructs if he won the presidential election. The cultivation of fear is also connected to the social assistance and aid programmes provided to the working class and unemployed people with claims that Ince would stop these programmes.

Following the hizmet/millet (service/nation) rhetoric that aims to cultivate the political fear in the second form, Erdoğan often moves into the narration of his leadership in relation to his main campaign message: 'A great Turkey needs a strong leader'. The discourse for strong leadership is presented in stark contrast to the weak leadership of the opposition, and grounded in the pious moralism of Islamic humbleness. Using the pronoun 'we' as a symbol of his modesty, he says on 9 June, 'we're the servant of the millet', 'we love the created because of the creator' and 'we never bow in front of anyone, except God when we pray'. His most compelling rival Ince, on the contrary, is often caricaturised variously as 'apprentice', who lacks the experience and knowledge to qualify for the state administration. Proposing an analogy between governing a country and running a business, he says on 10 June, 'would you let an apprentice to run your shop? Governing a country requires a strong leadership'. Referring to Ince's humorous style in his rally speeches, which are occasionally screened on television screens, Erdoğan says, 'you see him on television. He is a comic. But is it enough to govern the 
country?' He asks, 'Bay Ince, you think the millet will be fooled by you?' Erdoğan often ends this part of the rally by repeating the mantra 'the stronger the leader is, the greater the country is'.

In the last part of his speeches, Erdoğan talks about the threat of terror, thus shifting towards the first political fear and in doing so, he embraces the far-right nationalist discourse. The critiques against his regime concerning curtailment of democracy are also responded to in this context, always in connection to the threat of terrorism. While Demirtaş is the main target for his demonising rhetoric concerning the demand for democracy, Erdoğan also connects 'the Kurdish threat' to Ince, who has provided sympathetic messages to the Kurdish voters and also visited Demirtaş in prison as a gesture of solidarity against Erdoğan's vindictive rule. Erdoğan states on 7 June, 'Bay Ince claims he serves for democracy. What he really serves for is terror'. Characterised as either naïve or ill-willed, it is claimed that Ince is in partnership with the PKK and the international lobbies whose main aim is to finish off Erdoğan and the greatness of Turkey. Shouting, 'are you ready to give them such an Ottoman slap on June 24', Erdoğan ends his rally, 'we will work hard for this. No sitting back, no stopping'.

\section{News bulletins}

The evening news bulletins I analysed played a crucial role in the production and circulation of fear, anxiety and mistrust. Channels undertook different roles in the production of fear-mongering news content, by employing distinct styles, discursive modes and aesthetics for news presentation. Combining news and commentary, the most partisan channels, the privately owned ATV and A Haber, provided the most vulgar and philistine forms of war on terror propaganda. The two channels are owned by a group of Islamist clientele who undertake governmentally backed projects in infrastructure and housing construction as well as the energy business in Turkey and the Middle East (Yeşil, 2016). Their news bulletins are among the most watched and trusted news programming among Erdoğan supporters (KONDA, 2014; Table 1).

The male presenters on these two channels use very simple language and often repeat the main message of every news story when the camera turns to them after each news item. During the monitored week, the opening news stories were always related to the Turkish military operations in Northern Iraq and presented as actions of the governmental policy to 'eliminate terrorism'. The tone of emotionality is accentuated, as the news items include personalised stories of the soldiers killed in the battles, which are often presented as the heroic stories of martyrs. These stories were then followed by Erdoğan's speech in which he addressed the terror problem, cited a dead soldier's poem and attacked the opposition for supporting terrorism. Out of the oppositional contestants, only Ince and Demirtaş received any coverage on these news bulletins and this coverage was without exception negative. Demirtaş was always linked to the PKK, mostly by the news presenter stating that his 'terrorist' brother was in the mountains that were bombed by the Turkish air forces. While İnce was either connected to Demirtaş through his sympathy for pro-Kurd- ish politics or represented as a weak rival against Erdoğan. On 12 June, the presenter of A Haber remarks, "what we see in the rallies is the difference of experience and political skills'. On one hand, he says, 'we have someone who has spent more than 30 years in politics, undertook various roles in the state administration, and knows what the public needs, and how to communicate with the public'. On the other hand, the presenter suggests that 'we have inexperienced leaders'. This introduction is followed by footage from Ince's rally where he performs a local dance ('Zeybek') and where his bodyguards prevent a supporter from taking a selfie with Ince. Censoring the conservative and nationalist oppositional contestants, the election coverage on these news bulletins were designed to provide the sense that the electoral competition was taking place between Erdoğan, the terror-related imprisoned Demirtaş and the weak and unskilled Ince.

Following the screening of political content, these channels air crime and accident sto- ries, which take half the air time of the bulletins. Watching these programmes, the viewers are largely exposed to entertaining visuals of car crashes, drunk drivers stopped by the police and fights taking place in urban traffic. Serious crimes such as domestic violence, murders and the torture of street animals (dogs and cats) are often covered in relation to how the security forces and the government develop strategies to prevent the crime.

While the public TRT allocated the highest airtime to Erdoğan's speeches in daily coverage, the news bulletins were produced to give the impression of balance and objectivity by covering the other contestants' rallies. Quotations from the other contestants' speeches were selected from the parts where they engaged in polemics with Erdoğan. While the critiques made by the opposition were often corrected by footage of interviews with state officials. TRT 1 news was the only screen that represented the government with other state officials other than Erdoğan. 
Other major private channels (such as Habertürk, NTV, Star TV and Kanal D), whose owners had been in the media market before Erdoğan came to power in 2002 undertook a different role to support Erdoğanism. While the news on these channels were not characterised by the emotional, aggressive and explicit propaganda of Erdoğan's policies, the news content only included the stories that did not contradict the main narrative of Erdoğan's truth regime. For instance, the news bulletins on the monitored week had almost no coverage of the economy, nothing on political repression, Kurdish politics or the daily obstruction that oppositional parties face in their campaigns. Likewise, there were no facts-checks of Erdoğan's untruthful 'truth' claims. Instead, they covered the military operations as the first and main news of the evening bulletins in their own formalistic style, followed by contestant's daily speeches/rallies and other stories that were distributed by the state-run news agency. Their election coverage did include the other oppositional leaders' campaigns, however, similar to TRT, this coverage was mostly limited to quotations taken from the contestants' polemics with Erdoğan rather than covering their manifestos and projects. On these channels, the news items were predominantly presented by female hosts without any commentary, unlike their male counterparts on ATV and A Haber, for example, who summarise the news stories.

Show TV, Kanal D and Star TV, channels which have historically been associated with tabloid journalism in Turkey's television sector, allocated more than half of their airtime to crime and accident stories. When crime stories also found space in the news channels' coverage (Habertürk and NTV to a lesser degree), they became the main political content of these channels. The coverage of domestic violence, the horrifying torture of street animals by locals in conservative cities and the kidnap of a little girl in Istanbul were the main stories through which they could set the news agenda. These stories were subsequently referenced by oppositional candidates as symptoms showing the moral decay of Turkish society and the rising collective sadism and evilness among some segments of the society under vindictive authoritarian regime (ccc. such discussions, of course, were not televised, but became popular on some digital and social networks; Table 2).

The Turkish Fox, which is the most popular channel for news consumption among the secularist voters, appears to be the only channel that challenges Erdoğan's narrative with news stories and commentary by the male hosts. For instance, during the monitored period, Fox news bulletins were the only televisual site where Erdoğan's lies, such as the fact that Erdoğan did not go to school during the single-party period, were challenged by the host who asked, 'why is Erdoğan doing this?' Importantly, the oppositional contestants' rallies and speeches were equally covered on this channel as well as a contextualisation of the oppositional parties' projects and manifestos. The election coverage also included stories depicting the governmental obstructions of the opposition party's campaign. The ironic character of this localised version of global right-wing conservatism and far-right populism, though, is largely limited to the critique of Erdoğan's Islamist discourses and his attacks on the secularist-Kemalist past. On one hand, its seemingly critical news programming contributes to the general propaganda discourse negating the critique of the loss of freedom of expression and press under Erdoğan's reign. On the other hand, its global connections to the US neo-cons is conveniently used by Erdoğan's televisual propagandists to discredit the critical news content as the continuous operations of the US-led Western interventionist policies.

\section{Debate programmes}

In the current political economic structure of television, this format has evolved into a primary televisual site where journalists, experts and researchers, most of whom were not known to the public before the authoritarian turn, discredit and falsify any truth claims that contradict with Erdoğanism. By borrowing Bourdieu's concept, the Turkish sociologist Bahadır Türk (2013) defines the usual invitees of this format as 'technicians of opinions' who are characterised by their unlimited will to hold power, self-confidence and passion to say a word about everything. During the campaign period, the main task of these technicians was to both rationalise and glorify the military operations as an anti-imperialist project and a strong determination to protect national sovereignty and security against the international lobbies' anti-Erdoğanist policies. The leftist critique of the geopolitics of power, the conspiracy theories (where Israel and US play major role in organised evilness), and the liberal and Islamist critique of self-Orientalist policies of the Kemalist past are all appropriated into a ludicrous narrative. This narrative is deployed by the 'technicians of opinion' to relentlessly contextualise, historicise and rationalise the fear of terror and chaos.

On commercial news channels, such as Habertürk, CNN Türk and NTV, which are not owned by Islamic clientele, the rational sounding technicians engage in a parody of conciliatory debate where they perform national salvation rhetoric against the claims made by the representatives of the opposition (mostly from the 
CHP). In most cases, the CHP reps are caught in a defensive position, claiming that they are also nationalists and that they are just as well aware of the threats against national security.

In the partisan public TRT Haber and commercial A Haber's debates, discussion takes place only between the salaried propagandists where they compete with each other to perform the most passionate advocacy of Erdoğan's militarist approach and nationalist rhetoric. Furthermore, they lynch all other political views, which are unrepresented in the debate, as supporters of Western imperialism and international terrorism. The most grotesque interpretations of international and national politics are provided in such settings. On 12 June, Derin Analiz (2018), a debate programme on the public TRT Haber channel, Yiğit Bulut, a financial analyst and Erdoğan's personal consultant, stated,

PKK is a dog of imperialist power. FETO and PKK are managed by the same imperialist centre. Those who critique military operations in Qandil, Menbic and other parts of the borders are betraying their country. Look, I am not a partisan person. I do not support any political party. But I support Erdoğan. Because he is struggling against all forms of imperialism, today. Turkey is the only anti-imperialist country under his leadership ... People of Turkey should understand that this is not about politics [political competition]. What is at stake today is the war and struggle against imperialism in financial markets.

During another debate, screened on the A Haber channel (Memleket Meselesi, 2018) on 12 June, the invitees discuss the CHP's claim that there were no PKK militants in Qandil at the time of military operations. A media professor, who later became the Press Relations consultant of Erdoğan after the June elections, asked 'is CHP the advocate of terrorists?', and expressed his astonishment at their critique of 'the first comprehensive operation against terrorism not only in the history of Turkey but also in the world'.

In such debates, the new presidential system where all executive powers are aggregated under the authority of a strong president is portrayed as bringing an end to all threats to national security, and the beginning of a new period where the millet can finally be at peace, freed from the troubles of old Turkey.

\section{Conclusion}

The election resulted in a record level of turnout (87.5\%), another victory of Erdoğan with $52.6 \%$ of the vote in the first run and an outright majority of his coalition in the parliament with $53.6 \%$ of the electoral support. While the television representation was not the only factor that generated this electoral victory for Erdoğanism, it provided a continous and constant narrative, showing the reasons and excuses for why Erdoğan, his party and his coalition should run the country and change the political system from an ill-functioning parliamentary system to the Turkish type presidency in which the elected leader would have Sultanic powers. As the oppositional parties mobilised their voters and generated significant hope and optimism in online spaces as well as in rally areas, their campaign and manifestos were largely ignored in televisual circuits. Lacking televisual representation, they were largely demonised and received only negative coverage.

Erdoğan's screens and genres provided various forms of modality and expression for the telling and narrating of political fear and popular truth as the core of televisual idiom during the election period. As Erdoğan kept giving his speeches on daily basis, he reminded his supporters that all material gains and benefits they have attained under his leadership is dependent on his success in the electoral competition. The dystopic narrative of the future and the past without Erdoğan also fuelled the fear that it is not only social status, wealth and welfare benefits at stake. The millet's security, the survival of the nation and maintenance of national sovereignty is also under threat. Adopting different discursive styles and modes, news programming supported the narrative of political fear by providing seemingly factual evidences for untruthful discourses as well as by not challenging and factchecking repeated lies. The debate programmes provided various forms of parodies where the objects of fear are defined, contextualised and related to the contradictory and conflicting ideological discourses in spectacular ways. In their grotesque analysis of international and national politics, the salaried propagandists provided monumental examination of enemies that range from the secularist opposition party to the PKK, from the international interest and energy lobbies to Kurdish politicians. As complementary components of Erdoğan's screens, each of these segments of programming functioned to create a unified and coherent narrative - there would be chaos without Erdoğan, or security and wealth with his pious and strong leadership.

The case study on Erdoğan's screens during the 2018 elections period shows that the exponential growth of digital and social media in the world's communicative sphere did not result in the death of television as a powerful political medium. Television continues to undertake a key role for political mediation, production of truth regimes and political fear for a middle and working class audience in Turkey and elsewhere. Its popularity 
as the main news medium, and its variety in terms of journalistic genres and formats are exploited by the strongman politics to multiply and diversify the modes of telling, while simultaneously narrating a unified and coherent narrative that justifies the authoritarian rule. The neoliberal restructuration of television (and communication sector in broader terms) sector is essential to the appropriation of television for the making and endurance of strongman politics. Further research in political communication and non-western media studies should not disregard the role of neoliberal television in the authoritarian- populist politics across the world.

\section{References}

Akın A (2016) Conditions of sense making and news making in Turkey after the failed coup attempt: Sisyphus labor on two fronts. Journalism 18(4): 518-32.

Akser M and Baybars-Hawks B (2012) Media and democracy in Turkey: Towards a model of neoliberal media autocracy. Middle East Journal of Culture and Communication 5: 302-321.

Andrejevic M (2013) Infoglut: How too much information is changing the way we think and know. New York: Routledge.

Arsan E (2011) Sivil İtaatsizlik Bağlamında Bir Araştırma: Gazeteci Gözüyle Sansür ve Otosansür [A Research in the Context of Civic Disobedience: Censorship and Autocensorship From the Lens of Journalists]. Cogito 67: 1-29.

Bek MG (2004) Tabloidization of news media: An analysis of television news in Turkey. European Journal of Communication 19(3): 371-386.

Bora T (2017) Cereyanlar: Türkiye'de Siyasi Ideolojiler [Trends in Political Ideologies in Turkey]. Istanbul: Birikim.

Bruff I (2014) The rise of authoritarian neoliberalism. Rethinking Marxism 26(1): 113-129.

Bulut E and Yörük E (2017) Digital Populism: Trolls and Political Polarization of Twitter in Turkey. International Journal of Communication 11: 4093-4117.

Chakravartty P and Roy S (2015) Mr. Modi goes to Delhi: Mediated populism and the 2014 Indian Elections. Television \& New Media 16(4): 311-322.

Cizre Ü (2018) 'Vetocu Demokrasi', Siyasal Korku ve Vazgecilmez 'Lidere Meftunluk' [Negative Democracy, Political Fear and the Indispensable Emotional Attachment to a Leader]. Birikim 352. Available at: http://www.birikimdergisi.com/birikimyazi/9052/vetocu-demokrasi-siyasal- korku-ve-vazgecilmez-lidere-meftunluk\#.XBqBoXecaog.

Deacon D and Smith D (2017) The politics of containment: Immigration coverage in UK General Election News coverage (1992-2015). Journalism. Epub ahead of print 4 July. DOI: 10.1177/1464884917715944.

Derin Analiz (2018) TRT HABER. Directed by TRT HABER and hosted by Hasan Kurtulmus, 12 June.

Dorlach T (2015) The prospects of Egalitarian capitalism in the global south: Turkish social neo- liberalism in comparative perspective. Economy and Society 44(4): 519-544.

Eder M (2014) Deepening neoliberalisation and a changing welfare regime in Turkey: Mutations of populist, 'Sub-Optimal' democracy. In: Rodriguez C, Avalos A, Y1lmaz H, et al. (eds) Turkey's Democratisation Process. New York: Routledge, pp. $195-220$.

Ennis S (2015) How TV propaganda is affecting Russian society. BBC Monitoring, 25 August. Available at: https://hackerfall.com/story/how-tv-propaganda-is-affecting-russian-society.

Ethical Journalism Network (EJN) (2018) Turkey: Elections in a fake news climate. Green European Journal. Available at: https://www.greeneuropeanjournal.eu/turkey-elections-in- a-fake-news-climate/.

Gale P (2004) The refugee crisis and fear. Populist politics and media discourse. Journal of Sociology 40(4): 321-340. 
Getmansky A and Zeitoff T (2014) Terrorism and voting: The effect of rocket threat on voting in Israeli Elections. American Political Science Review 108(3): 588-604.

İnsel A (2018) Erdoğanizm Turkiyesi [Turkey of Erdoğanism]. Cumhuriyet, 10 July. Available at: http://www.cumhuriyet.com.tr/koseyazisi/1022093/erdoganizm-turkiyesi.html.

KONDA (2014) Kitle Iletişim Araçlarının Etkisi [The Impact of Mass Media]. Available at: https://konda.com.tr/tr/rapor/kitle-iletisim-araclarinin-etkisi/ .

KONDA (2018) Seçmen Kümeleri: AK Parti Seçmeni [Electoral Groups: AK Party Supporters]. Available at: http://konda.com.tr/tr/rapor/secmen-kumeleri-ak-parti-secmenleri/.

Maxwell R and Miller T (2018) Is television dying? Psychology Today, 6 November. Available at: https://www.psychologytoday.com/us/blog/greening-the-media/201811/is-television-dying.

Media Ownership Monitor (MOM) Turkey (2016). Avallable at: http://turkey.mom-rsf.org/

Memleket Meselesi (2018) A Haber. Directed by A Haber News and hosted by Duygu Leloğlu, 12 June.

Miskimmon A, O'Loughlin B and Roselle L (2014) Strategic Narratives: Communications Power and the New World Order. New York: Routledge.

Morgan M and Shanahan J (2017) Television and the cultivation of authoritarianism: A return visit from an unexpected friend. Journal of Communication 67: 424-444.

Oates S (2017) A perfect storm: American media, Russian propaganda. Current History 116(792): 282-284.

Onis Z (2016) Democracy in uncertain times: Inequality and democratic development in the global north and global south. METU Studies in Development 43(1): 317-336.

Ornstein N and Mann T (2000) The Permanent Campaign. Washington, DC: The Brookings Institution.

Organization for Security and Co-operation in Europe (OSCE) (2018) Turkey, early Presidential and Parliamentary Elections, 24 June 2018: Interim Report. Available at: https://www.osce.org/odihr/elections/turkey/384600.

Pamuk S (2012) Türkiye'nin 200 Ylllık Iktisadi Tarihi [The Economic History of Turkey in 200 Years]. Istanbul: Is Bankasi Yayınları.

Radyo Televizyon Yayincilari Meslek Birligi (RATEM) [Radio Television Broadcasters Association] (2018) Turkiye Radyo ve Televizyon Yayinciligi Sektor Raporu. Available at: https://www.ratem.org/sektor-ozet-raporu.

Robin C (2006) Fear: The History of a Political Idea. Oxford: Oxford University Press. Roudakova N (2017) Losing Pravda: Ethics and the Press in Post-Truth Russia. Cambridge: Cambridge University Press.

Saka E (2016) Siyasi Trollük örneği olarak Aktroller [Aktrolls as examples of political trolling]. Birikim 322: 17-21.

Schedler A (2002) Elections without democracy: The menu of manipulation. Journal of Democracy 13: 36-50.

Smythe D (1954) Reality as presented by television. Public Opinion Quarterly 18(2): 143-156.

Somer M (2016) Understanding Turkey's democratic breakdown: Old vs new and indigenous vs global authoritarianism. Southeast European and Black Sea Studies 16(4): 481-503.

Sudibyo A and Patria N (2013) The television industry in post-authoritarian Indonesia. Journal of Contemporary Asia 43(2): $257-275$.

Türk B (2013) Kanaat Teknisyenliği Dünyasının Yeni Yıldızları: AKP Medyasının Zorlu Ikilisi Olarak Rasim Ozan ve Nagehan Alçı [New Starts of The World of Technicians of Opinions: Rasim Ozan and Nagehan Alçı as Duo of AKP Media]. Birikim. Available at: http://www. birikimdergisi.com/guncel-yazilar/517/kanaat-teknisyenligi-dunyasinin-yeni-yildizlariakp- medyasinin-zorlu-ikilisi-olarak-rasim-ozan-ve-nagehan-alci\#.W3IDIX59igA. 
Ucankus (2018) Ratingler. Available at: https://www.ucankus.com/ratingler.

Uras U (2016) Turkey: Why did Erdoğan call early elections? Aljazeera, 4 June. Available at: https:// www.aljazeera.com/indepth/features/erdogan-call-snap-elections-turkey-180418191340799.html.

Waisbord S (2018a) Truth is what happens to news. Journalism Studies 19 (13): 1866-1878.

Waisbord S (2018b) Why populism is troubling for democratic communication. Communication Culture \& Critique 11:2134.

Wodak R (2015) The Politics of Fear: What Right-Wing Populist Discourses Mean. London: SAGE.

Yeșil B (2016) Media in New Turkey: The Origins of Authoritarian Neoliberal State. Chicago, IL: University of Illinois Press.

Yıldırım D (2009) AKP ve Neoliberal Populizm [AKP and Neoliberal Populism]. In: Uzgel I and Duru B (eds) AKP Kitabl: Bir Dönüşümün Bilançosu [A Book of AKP: Tracing the Transformation]. Ankara: Phoenix Yayinevi, pp. 66-107.

Y1lmaz I and Bashirov G (2018) The AKP after 15 years: Emergence of Erdoğanism in Turkey. Third World Quarterly 39 (9): 1812-1830.

Yılmaz Z (2018) Yeni Türkiye'nin Ruhu: Hınç, Tahakküm, Muhtaçlaştırma. Istanbul:Iletişim. [The Spirit of New Turkey: Resentment, Oppression, Dependency] 
Table I. The percentage of news content on mainstream evening news bulletins.

\begin{tabular}{|c|c|c|c|c|c|c|c|c|c|}
\hline Content & ATV & Show & Ahaber & Fox & Habertürk & TRTI & NTV & Star & Kanal D \\
\hline Incumbent coalition & 27.8 & 7.6 & 22.2 & 40 & II.I & 14.2 & 23.8 & 8.3 & 19.1 \\
\hline Opposition & 16 & 10.4 & 16.6 & 35 & 11.1 & 50 & 14.2 & 8.3 & 9.5 \\
\hline Crime/accidents & 27.8 & 50 & 22.2 & & II.I & & 4.7 & 54.1 & 47.6 \\
\hline Human interest & 5.6 & 11.6 & 5.5 & & 5.5 & 7.1 & 9.5 & 8.3 & 9.5 \\
\hline Celebrity & & 3.8 & & 10 & 5.5 & & 4.7 & & \\
\hline Economy & & & & 5 & 5.5 & & 9.5 & 4.1 & \\
\hline War/terror & 22.2 & 11.6 & 22.2 & 5 & 16.6 & 14.2 & 9.5 & 12.5 & 9.5 \\
\hline Politics - other & & 3.8 & 5.5 & & 5.5 & 7.1 & 9.5 & 4.1 & 4.7 \\
\hline International & & & 5.5 & 5 & 27.8 & 7.1 & 9.5 & & \\
\hline Culture & & & & & & & 4.7 & & \\
\hline
\end{tabular}

Table 2. Themes in Debate Programmes.

\begin{tabular}{ll}
\hline Channels & Themes \\
\hline A Haber & $\begin{array}{l}\text { Military operations in Northern Iraq, terror, the CHP, Western imperialism } \\
\text { and links to the PKK terrorism } \\
\text { The American/Turkish relations in the context of war on terror, polemics } \\
\text { between the candidates, and interviews with the candidates, including the } \\
\text { oppositional leaders }\end{array}$ \\
The new and old political system, opinion polls, terror and the PKK, military \\
CNNTurk & $\begin{array}{l}\text { operations in the Northern Iraq, the CHP, interviews with the candidates, } \\
\text { including the oppositional leaders, the mysticism of Rumi }\end{array}$ \\
Haberturk & $\begin{array}{l}\text { Military operations in the Northern Iraq, opinion polls, interviews with the } \\
\text { oppositional leaders, modernity and Islam }\end{array}$ \\
TRT Haber & $\begin{array}{l}\text { The 'new political system', Western imperialism and its links to the PKK } \\
\text { terrorism, international energy lobbies against Turkey, military operations in } \\
\text { Northern Iraq }\end{array}$ \\
\hline
\end{tabular}

CHP: Republican People's Party; PKK: Partiya Karkarên Kurdistanê. 